\title{
Assessment Instruments of Social Attitudes and Social Studies Learning Outcomes for Class V SD on Theme of Lingkungan Sekitar Kita
}

\author{
Ni Komang Suci Yundarini ${ }^{1}$,Dewa Nyoman Sudana ${ }^{2}$,I Gede Astawan ${ }^{3}$
}

1,2,3,4 Department of Basic Education, Ganesha University of Education, Singaraja, Indonesia

\begin{tabular}{l} 
A R T I C L E I N F O \\
\hline Article history: \\
Received February \\
2020 \\
Received in revised \\
Form 01 March 2020 \\
Accepted 18 July 2020 \\
Available online 30 \\
August 2020
\end{tabular}

Keywords:

Instrument, social attitudes, social learning outcomes, $4 D$ model

\begin{abstract}
A B S T R A C T
The assessment instrument is an important component needed in the learning assessment process. However, in practice, there are still many teachers who have not been able to produce quality assessment instruments. The purpose of this study was to produce valid and reliable assessment instruments for social attitudes and social studies learning outcomes in class $\mathrm{V}$ on theme of lingkungan sekitar kita. In this study using a 4D development model, namely define, design, develop, disseminate. In this development research, it is only up to the development stage. The instrument used for the assessment of social attitudes was a questionnaire (questionnaire), while for the assessment of social studies learning outcomes used was a multiple-choice test. The data obtained would be analyzed the validity and reliability of each assessment instrument. The results of the analysis of the validity of the social attitude assessment instrument and social studies learning outcomes obtained an average value of 1 , which means that the two assessment instruments have very high validity, while the results of the analysis of the reliability of the social attitude assessment instrument are 0,89 and the reliability of the social studies
\end{abstract} learning outcomes assessment instrument is $0,89.0,85$ which means that these two instruments have a high level of reliability. From these results, it can be concluded that the development of an assessment instrument for social attitudes and social studies learning outcomes is feasible to use in assessing students.

\section{Introduction}

In the era of the Industrial Revolution 4.0 as it is today, the development of science and technology is very rapid. This requires each individual to be able to utilize information technology appropriately. Therefore, it requires qualified Human Resources (HR). The quality of human resources can be improved through education. Education plays an important role in preparing human resources and being able to make changes for the Indonesian nation towards a better direction, especially in development growth (Widiansyah, 2017; Kusaeri et al., 2018). Education will also give birth to students who are smart and have competencies and skills to be developed during society (Mardika, 2017). Education is one of the tools to produce a change in a person so that it can form a better character through the learning process. In a narrow sense, education is closely related to learning.

Education in Indonesia, especially at the primary school level, has changed, especially in improving the curriculum. Currently, all elementary school levels are implementing the 2013 Curriculum so that the technical learning process has also changed. Learning is an effort that is carried out effectively and cannot be separated from the role of an educator. According to (Rusman, 2017), Learning is a series of educational processes that provide opportunities for students to be able to develop their potential both from attitudes, knowledge, and skills. For learning to be successful, students must develop their potential and be able to overcome existing problems (Antari et al., 2016). In the learning process in the classroom, educators are not only as facilitators but also as evaluators or assessors to determine the achievement of predetermined goals. Learning can be called successful if all components have been achieved properly. The component used by educators to measure the success of the learning process is assessment.

Assessment is carried out to measure the achievement of students' competencies on an ongoing basis in the learning process, to monitor the progress and improvement of learning outcomes of students (Mustafa et al., 2019; Kastina \& Sujianto, 2017). Based on Permendikbud Number 23 of 2016 concerning assessment standards, it is defined as the process of collecting and processing information to measure the 
achievement of learning outcomes of students. The assessments carried out include aspects of attitudes, aspects of knowledge, and aspects of skills (Setiadi, 2016). According to (Wicaksono, 2016), Affective aspects possessed by students greatly affect the condition of students in cognitive and psychomotor aspects. Therefore, educators are expected to be able to make assessment instruments and carry out assessments both from the affective, cognitive, and psychomotor aspects appropriately.

But in reality, teachers still have difficulty in developing test and non-test assessment instruments in accordance with the rules. Assessment tests are used to measure social studies learning outcomes and non-test assessments are used to measure the social attitudes of students. The purpose of social studies learning in schools is to learn about aspects related to human life and their social environment. Social studies subjects in elementary schools are very identical to subjects that explore in-depth the interaction or relationship with social problems that occur in society (Atmaja et al., 2019). Trianto (Suryani \& Aman, 2019) states that IPS is an integration of social science branches. Social Science or what is often known by the abbreviation IPS is one of the subjects taught in elementary schools. Social studies are defined as a subject that combines social sciences, humanities, state ideology, and religion which have been compiled through educational approaches and psychological considerations which will later benefit the lives of Kertih students (Arrasyid et al., 2017).

In the social studies learning process, social attitudes are needed in interacting with other people. In school, students are instilled with social attitudes by the teacher, namely honesty, discipline, politeness, caring, responsible, and confident, so it is hoped that this social attitude can become a culture for every student. Social attitude is an action that reflects a person to be able to live in society, namely by helping each other, mutual respect, and mutual respect for one another (Sanjiwana, et, al., 2015; Kusuma, 2017). In line with Ahmadi's opinion Ahmadi (Virani et al., 2016) that social attitude is the awareness that each individual has in doing real and repetitive actions. Assessment of social attitudes is carried out to determine the development of students' social attitudes in behaving honestly, disciplined, caring, polite, confident, in interacting with the social environment (Surahman \& Mukminan, 2017; Gusviani, 2016). If every student has a good social attitude, it will be able to influence social studies learning outcomes.

The results of observations and interviews conducted with class V teachers from 19 October 2019 to 23 October 2019 revealed several facts which showed that 1) the teacher had not been seen in assessing in terms of aspects of social attitudes in social studies learning. 2) teachers tend to use one type of assessment, teachers have difficulty using assessments in the learning process. 3) assessment of social attitudes only in making assignments and the behavior of students, as well as through observations during the learning process. 4) the teacher is still having difficulties in the process of making instruments. 5) teachers tend to have difficulty developing test assessment instruments, especially in measuring students' social studies learning outcomes.

Responding to problems that occur in the field, it is necessary to make efforts that can be made by the teacher to facilitate the assessment process carried out. Teachers need an assessment instrument that can assess the results according to the conditions or circumstances being assessed. Teachers can easily develop assessment instruments to assess social attitudes and social studies learning outcomes.

Research on the development of relevant assessment instruments is research conducted by (Juniarta \& Winarno, 2016) which indicates that the assessment instrument has 119 items that meet the standard criteria well. Then the research was conducted by (Candra et al., 2018) which indicates that the social attitude assessment instrument with valid statement items. Also supported by research by (Muslimah et al., 2017) which indicates that the social attitude assessment instrument developed is valid, reliable, and worthy of use. Research by (Desilva, 2020) which shows that the validity results of the HOTS multiple-choice instrument are in the valid category.

From the research above, there are differences from this study. In this study, two instruments were developed, namely an instrument for assessing social attitudes and an instrument for assessing social studies learning outcomes. This research has the advantage for teachers to know the progress of students during the learning process both in terms of attitudes and learning outcomes. The attitudes shown by students can influence assessment in the learning process. The social attitude assessment instrument developed in this study was a social attitude assessment instrument in the form of a questionnaire and the social studies learning outcome assessment instrument developed was a multiple-choice test (objective). Based on the description above, the purpose of this study is to produce the validity and reliability of the instrument for assessing social attitudes and social studies learning outcomes in grade V SD on the theme of Our Friends' Environment. 


\section{Methods}

The research method used in the study on the development of instruments for assessing social attitudes and learning outcomes of social studies in grade V SD on the theme of Our Environment was Research and Development (R\&D). The model used in this research was the 4D development model. According to Thiagarajan (Kurniawan, 2017; Dewi \& Akhlis, 2016), There are four stages in the 4D development model, namely, define, design, develop, disseminate.

The implementation of the four stages in this study was as follows, in the first stage, define was the initial stage in carrying out a study, consisting of needs analysis, student characteristic analysis, and task analysis. The second stage was planning (design), which was the stage in planning and producing an assessment instrument, consisting of the preparation of a grid and the initial design. The arrangement of the grid was in accordance with the indicators of competency attainment and the initial design in developing an assessment instrument for social attitudes and social studies learning outcomes in the form of questionnaires and multiple-choice tests the indicators assessed on social attitudes were honesty, discipline, responsibility, courtesy, care, and confidence. As for social studies learning outcomes by determining the Core Competencies and Basic Competencies contained in theme 8 Our Friends Environment. The third stage was the development (develop) which was the stage used to develop the assessment instrument, consisting of expert validation carried out by material experts and testing the development of social attitude assessment instruments and social studies learning outcomes carried out in grade V at SD Madrasah Ibtidaiyah Negeri 3 Karangasem with the number and SD Negeri 9 Subagan.

The population in this study were all students of grade $\mathrm{V}$, amounting to 75 students. The variables used in this study were instruments for assessing social attitudes and social studies learning outcomes. The data in this study were collected using non-test and test methods. Social attitudes were collected using the non-test method in the form of a questionnaire (questionnaire) as many as 35 items. Social studies learning outcomes were collected using a test method, namely an objective test instrument (multiple choice) of 35 items. The data analysis technique used was the analysis of the validity of the instruments and the analysis of the reliability of the instruments. In the analysis of the validity of the instrument consisted of content validity and item validity tests. This study analyzed the reliability of social attitudes and social studies learning outcomes.

\section{Result and Discussion}

The results of the initial product development in this study were an instrument for assessing social attitudes and learning outcomes of class V Social Studies on the theme of Our Surrounding Environment which was used to measure social attitudes and social studies learning outcomes of students. The student's social attitude assessment instrument was a questionnaire (questionnaire) and consisted of 35 statements. The learning outcome assessment instrument was a multiple-choice test consisting of 35 questions. The instruments for assessing social attitudes and social studies learning outcomes were prepared in this study. According to Harumurti (Primandari, 2019), which are assessed in the aspect of social attitudes include being honest, disciplined, responsible, polite, caring, and having self-confidence. The dimensions of social attitudes were developed into 35 statements, 18 positive statements, and 17 negative statements using an assessment instrument in the form of a questionnaire (questionnaire).

Development of a social attitude assessment instrument in the form of a grid and a questionnaire with a total of 35 statements and an assessment of the content validity test with two judges. The results of data analysis showed that 30 items were relevant and 5 items were irrelevant. The next stage was to test the validity of the items and their reliability, the results of the analysis of the validity and reliability of the social attitude assessment instrument, to test the reliability of the social attitude questionnaire using valid statement items while invalid statement items are removed from the instrument (Candiasa, 2011). The reliability test of the social attitude questionnaire was calculated with the help of the Microsoft Office Excel 2010 program. The results of the analysis of the validity and reliability of the social attitude instrument can be seen in Table 1.

Table 1. The results of the analysis of the validity and reliability of the social attitude assessment instrument

\begin{tabular}{ccc}
\hline Analysis & Result & Criteria \\
\hline Content Validity & 1,00 & Very High \\
Reliability & 0,89 & Very High \\
\hline
\end{tabular}


Based on Table 1 above, the results of the analysis of the content validity of the social attitude instrument using the Gregory formula were obtained at 1.00 and we're at the very high content validity criteria. The results of the analysis of the instrument reliability test using the Alpha-Cronbach formula were found to be 0.89 having very high-reliability criteria.

The development of social studies learning outcomes assessment instruments is prepared based on basic competencies and according to the subject syllabus on theme 8 Our Friends' Environment. The instrument used to measure social studies learning outcomes was a multiple-choice test. The social studies learning outcomes test consists of 35 questions. Each question is accompanied by four alternative answers chosen by the student (alternatives $a, b, c$, and d). The resulting instrument will be tested for content validity by judges' experts and item validity which shows that of the 35 questions only 30 items are relevant. The next stage is carried out a reliability test on the social studies learning outcomes instrument, the results of the content validity analysis, and the social studies learning outcomes instrument reliability can be seen in Table 2 .

Table 2. The results of the analysis of content validity and reliability of social studies learning outcomes instruments

\begin{tabular}{ccc}
\hline Analysis & Result & Criteria \\
\hline Content Validity & 1,00 & Very High \\
Reliability & 0,85 & Very High \\
\hline
\end{tabular}

Based on Table 2 above, the results of the analysis of the content validity of the social studies learning outcomes instrument by using the Gregory formula were obtained at 1.00 and were at very high content validity criteria. The results of the analysis of the instrument reliability test using the KuderRichardson 20 (KR-20) formula assisted by the Microsoft Office Excel 2010 program. For the reliability test of social studies learning outcomes using valid test items while invalid statement items were excluded from the reliability calculation (Candiasa, 2011). The results obtained from the reliability test of 0.85 have very high-reliability criteria.

Based on the descriptions and research reports that have been previously described, the development of an assessment instrument for social attitudes and social studies learning outcomes with the 4D model goes through the defined stage, design stage, development stage, and disseminate stage. However, the disseminated stage cannot be implemented due to time constraints.

In the first stage, namely define, which includes needs analysis, characteristics analysis, and task analysis. In a needs analysis to find out the needs of students, it is necessary to make instruments (Tegeh et al., 2019). Activities in analyzing needs, namely the unfulfilled needs, lead to low social attitudes of students and fewer student learning outcomes. From the results of the needs analysis, it shows that there is a need for an instrument for assessing social attitudes and social studies learning outcomes in grade $V$. Characteristic analysis found a problem, namely, students have very low social attitudes and social studies learning outcomes and still do not care about others. Task analysis is used in determining the material used in the social attitude assessment instrument and social studies learning outcomes. The material is emphasized through the preparation of indicators of cognitive and affective aspects so that it can be used in compiling a grid to measure social attitudes and mastery of class $\mathrm{V}$ social studies material on the 8 themes of our environment.

The second stage is (design) design which includes planning and preparing the design of an instrument for assessing students' social attitudes and learning outcomes of social studies. The design process consists of drafting a grid and initial design. The arrangement of the grid is carried out to determine the limitations of the material in social studies learning and as a guide in the process of making questions to fit the syllabus and the basic competencies used in the reference. The arrangement is adjusted to the applicable curriculum so that the instruments made can be easily answered by students (Pamungkas, 2019). Whereas in the initial design, the items of the questionnaire statement and questions on social studies learning outcomes were compiled based on the grid that had been made.

The third stage is the (develop) stage to produce the development of the assessment instrument (Lestari et al., 2019). The development stage includes validating expert tests and carrying out product development tests. At this stage, the expert test validation is carried out with an IPS expert, namely a lecturer who teaches the IPS course. After guidance and validation are obtained from expert tests and comments and suggestions, then revisions are made. The revised results are then ready to be tested in the form of an assessment instrument for social attitudes and social studies learning outcomes. Based on the validation of the expert test, it was found that the validity of content 1 on the social attitude instrument 
and social studies learning outcomes had very high criteria. The results of the instrument trial show that there are 30 valid questions out of 35 questions that have been tested. The results of the reliability analysis on the social attitude instrument amounted to 0.896 with a very high correlation coefficient category, the results of the reliability analysis of social studies learning outcomes that were 0.853 with a very high correlation coefficient value category. Based on the expert test validation analysis and the product development test, the social attitude assessment instrument and social studies learning outcomes can be continued at the dissemination stage. The fourth stage, the disseminate stage, cannot be implemented due to time constraints.

In this study, supported by the results of research by Ananda and (Fadhilaturrahmi, 2017), stated that the evaluation of social studies learning outcomes uses Bloom's Taxonomy. The learning outcomes of social studies subjects, the evaluation used were Prototype II after the trials were carried out so that the results of the validity, reliability, and practicality analysis were known. The total value of the validity analysis on the evaluation was 3.29 with the very valid category and the questions in numbers 1 to 6 with very high validity. The reliability test results of the test are 1.01 with very high criteria. From the results of the above research states that the evaluation tool developed has been declared practical for use in the field. Other supporting research is research conducted by (Mujadi, 2019), which indicated that the assessment instrument has been tested for validity with the result of 3.73 in the very good category. Based on the expert validity test analysis, it can be concluded that the product is very valid and suitable for use. As well as relevant research conducted by (Simarmata, 2019) which states that the level of validity of the instrument for assessing tolerance for thematic learning in grade IV SD has a low level of validity of $3.70 \%$, sufficient validity of $63 \%$, high validity of $33.3 \%$ of the 27 questions that have been compiled with a percentage of $100 \%$. In line with research (Utami \& Wardani, 2017), showed the validity results of 36 items and as many as 20 questions are taken according to the indicators and grid with good quality.

The instrument for assessing social attitudes and social studies learning outcomes deserves to be developed because the assessment instrument is a tool used in collecting data. In line with the opinion (Hardiani, 2017) The instrument is a tool used to facilitate the data collection process. So, a teacher in the learning process needs an assessment instrument to assess student learning outcomes using both test instruments and non-test instruments that both have valid and reliable criteria. In the research on the development of an assessment instrument for social attitudes and social studies learning outcomes, it can be said to be good because it has valid and reliable criteria and is suitable to be applied.

\section{Conclusion}

Based on the results of research and discussion, it can be concluded that the instruments developed are good and can be used. This can be seen from the results of the expert test assessment of the social attitude assessment instrument, the results obtained by the validity of content 1 on each instrument with very high criteria. The social studies learning outcome assessment instrument is well developed and can be used as well. This can be seen from the results of the validity test and the reliability test of the social studies learning outcomes instrument. The results of the instrument validity test showed that there were 30 valid questions from the 35 questions that had been tested. The result of the reliability test for social attitudes is 0.89 with a very high category of reliability so that it can be used to measure the social attitudes of students. The result of the reliability test of social studies learning outcomes was 0.85 with the very high-reliability category so that it could be used to measure students' social studies learning outcomes. The suggestions that can be conveyed based on the results of this study are that teachers should use an assessment instrument in accordance with what will be assessed. For schools, it can provide positive things in improving school quality. As well as for other researchers it can be used as material for consideration for the improvement and perfection of research that will be carried out next.

\section{References}

Ananda, Rizki dan Fadhilaturrahim.2017. "Evaluasi Pembelajaran IPS Berbasis Taksonomi Bloom Dua Dimensi di Sekolah Dasar". Jurnal Basicedu, Volume 1, Nomor 2, Halaman (12-21). DOI: 10.31004/basicedu.v1i2.2

Antari, Luh Putu Sri Wahyu., Suniasih, Ni wayan., \& Putra, I Ketut Adnyana. 2016. "Pengaruh implementasi model pembelajaran kooperatif type consept song berbasis lagu daerah terhadap hasil belajar IPS". E-journal PGSD Universitas Pendidikan Ganesha, Volume 4, Nomor 1, Halaman (1-10). http://dx.doi.org/10.23887/jjpgsd.v4i1.7238 
Arrasyid, Harun., I Wayan Lasmawan, Anak Agung Istri Ngurah Marhaeni. 2017. "Pengaruh Strategi Card Sort Terhadap Hasil Belajar IPS Ditinjau Dari Sikap Sosial Siswa Kelas V Gugus 1 Kecamatan Situbondo". e-jurnal program Pascasarjana Universitas Pendidikan Ganesha, Volume 14, Nomor 2 (hlm 119-126). http://dx.doi.org/10.23887/ijee.v2i2.14411

Atmaja, I Komang Adi Kusuma., Suniasih, Ni Wayan., \& Agustika, Gusti Ngurah Sastra. 2019. "Pengaruh Model Pembelajaran Kooperatif Tipe Concept Song Berbasis Lagu Anak Terhadap Kompetensi Pengetahuan IPS Siswa Kelas IV SD Negeri 3 Sukawati Tahun Ajaran 2018/2019". Jurnal Mimbar PGSD Undiksha, Volume 7, Nomor 2. http://dx.doi.org/10.23887/jjpgsd.v7i2.17988

Candiasa, I Made. 2011. Pengujian Instrumen Penelitian Disertai Aplikasi ITEMAN dan BIGSTEPS. Singaraja: Undiksha Press.

Candra, Intan, Sulistya, Naniek., Prasetyo, Tego. 2018. "Pengembangan Instrumen Sikap Sosial Tematik Siswa SD Kelas IV". Jurnal Ilmiah Sekolah Dasar, Volume 2, Nomor 4, Halaman (455-461). http://dx.doi.org/10.23887/jisd.v2i4.16167

Desilva, Dona., Sakti Indra., Medriati, Rosane. 2020. "Pengembangan instrumen penilaian hasil belajar fisika berorientasi HOTS (High Order Thingking Skill) pada materi elastisitas dan hukum hooke". Jurnal Kumparan Fisika, Volume 3, Nomor 1, Halaman 41-50. https://doi.org/10.33369/jkf.3.1.4150.

Dewi, Novi Ratna., \& Akhlis, Isa. 2016. "Pengembangan perangkat pembelajaran IPA berbasis pendidikan multikultural menggunakan permainan untuk mengembangkan karakter siswa". Unnes Science $\begin{array}{lllll}\text { Education } & \text { Journal, } & \text { Volume } & \text { 5, } & \text { Nomor }\end{array}$ https://journal.unnes.ac.id/sju/index.php/usej/article/view/9569.

Gusviani, Evi. 2016. "Analisis kemunculan sikap spiritual dan sikap sosial dalam kegiatan pembelajaran IPA kelas IV SD yang menggunakan KTSP dan kurikulum 2013". Edumaniora, Eduhumaniora jurnal pendidikan Dasar, Volume 8, Nomor 1, Halaman (96-100). https://doi.org/10.17509/eh.v8i1.5127

Hardiani, Iska Novi dan Naniek Sulistya Wardani. (2017). "Pengembangan Instrumen Penilaian Sikap Sosial Pembelajaran IPS Kelas IV SD". E-jurnal mitra pendidikan, Volume 1, Nomor 6, Halaman (615628).

http://download.garuda.ristekdikti.go.id/article.php?article=745292\&val=11748\&title=Pengemba ngan\%20Pengembangan\%20Instrumen\%20Penilaian\%20Sikap\%20Sosial\%20Pembelajaran\%20I PS\%20Kelas\%20IV\%20SD

Juniarta, Aswin Try., \& Winarno, M.E. (2016). "Pengembangan Instrumen Penilaian Pengetahuan Mata Pelajaran Pendidikan Jasmani Olahraga dan Kesehatan (PJOK) Kelas XI Semester Gasal". Jurnal Pendidikan, Volume 1, Nomor 8, Halaman (1659-1664). http://dx.doi.org/10.17977/jp.v1i8.6704

Kastina, Zulian Vina Kurnia., \& Sujianto. 2017. "Implementasi Sistem Penilaian dalam Kurikulum 2013 di SMA Negeri 2 Pekanbaru". Jurnal Online Mahasiswa Fakultas Ilmu Sosial dan Ilmu Politik Universitas Riau, Volume $4, \quad$ Nomor $1, \quad$ Halaman (1-15). https://jom.unri.ac.id/index.php/JOMFSIP/article/view/12720

Kurniawan, Dian \& Sinta Verawati Dewi. 2017. "Pengembangan Perangkat Pembelajaran Dengan Media Screencast-O-Matic mata Kuliah Kalkulus 2 Menggunakan Model 4-D Thiagarajan". Jurnal Siliwangi, Volume $3, \quad$ Nomor $1, \quad$ Halaman (214-219). http://jurnal.unsil.ac.id/index.php/jspendidikan/article/view/193

Kusaeri., Aditomo, Anindito., Ridho, Ali., \& Fuad, Zakki, Ah. 2018. "Socioeconomic Status, Parental Involvement In Learning And Student' Mathematics Achievement In Indonesian Senior High School". Jurnal Cakrawala Pendidikan, Nomor 3, Halaman (333-344). http://digilib.uinsby.ac.id/28934/

Kusuma, Putu Indra. 2017. "Pengaruh model pembelajaran resolusi konflik terhadap hasil belajar PKn ditinjau dari sikap sosial siswa kelas V SD gugus kolonel I Gusti Ngurah Rai Denpasar Utara". Jurnal Ilmiah Pendidikan dan Pembelajaran PPs Universitas Pendidikan Ganesha, Volume 1, Nomor 3, Halaman (229-239). http://dx.doi.org/10.23887/jipp.v1i3.11988

Lestari, Putri Eka., Purwanto, Andik., \& Sakti, Indra. 2019. “Pengembangan Instrumen tes keterampilan pemecahan masalah pada konsep usaha dan energi di SMA". Jurnal Kumparan Fisika, Volume 2, Nomor 3, halaman 161-168. https://doi.org/10.33369/jkf.2.3.161-168 
Mardika, I Putu., Parmiti, Desak Putu., \& Tirka, Wayan. 2017. “Pengaruh Model Pembelajaran Think Talk Write Terhadap Keterampilan Membaca Bahasa Indonesia Siswa Kelas III SD". Mimbar PGSD, Volume 5, Nomor 2 (hlm. 1-9). http://dx.doi.org/10.23887/jjpgsd.v5i2.10600

Mujadi. 2019. "Pengembangan Instrumen Penilaian Sikap Sebagai Upaya Optimalisasi Penerapan Nilainilai Yang Terkandung Dalam Mata Pelajaran Akidah Akhlak Kelas VI Madrasah Ibtidaiyah". Jurnal Pendidikan Dasar Islam, Volume 11, Nomor 01, Halaman (138-174). https://doi.org/10.14421/albidayah.v11i01.172

Muslimah, Ima., Nugraha, akhmad., Hamdu, Ghullam. 2017. "Pengembangan instrumen penilaian sikap sosial pada outdoor learning di sekolah dasar". PEDADIDAKTIKA: Jurnal Ilmiah Pendidikan Guru Sekolah Dasar, Volume 4, Nomor 1, Halaman (158-167). https://ejournal.upi.edu/index.php/pedadidaktika/article/view/7204

Mustafa, Pinton Setya., Winarno, M. E., \& Supriyadi. 2019. "Penilaian Pendidikan Jasmani, Olahraga, dan Kesehatan pada Sekolah Menengah Pertama Negeri Kota Malang". Jurnal Pendidikan, Volume 4, Nomor 10, Halaman (1364-1379). http://dx.doi.org/10.17977/jptpp.v4i10.12845

Pamungkas, Nugraha Tri Sukma. 2019. "Pengembangan alat evaluasi berbasis computer test (CBT) pada materi jurnal penyesuaian perusahaan dagang di SMA Negeri 1 Puri Mojokerto". Jurnal Pendidikan Akuntansi, Volume 07, Nomor 01, Halaman (90-95). https://jurnalmahasiswa.unesa.ac.id/index.php/jpak/article/view/29339

Permendikbud Nomor 23 Tahun 2016 Tentang Standar penilaian.

Primandari, Putri Amalia., Bambang Suteng Sulasmono, Eunice Widyanti Setyaningtyas. 2019. "Perbedaan Pengaruh Model Kooperatif Tipe TGT dan STAD Dengan Multimedia Interaktif Ceria Terhadap Sikap Sosial Dan Hasil Belajar Kognitif Pada Pembelajaran Tematik Kelas 5 SD". Jurnal Basicedu, Volume 3, Nomor 1 (hlm. 83-91). https://doi.org/10.31004/basicedu.v3i1.82

Rusman. 2017. Belajar dan Pembelajaran Berorientasi Standar Proses Pendidikan. Jakarta: Kencana

Sanjiwana, Pande Putu Cahya Mega., Pudjawan, Ketut., \& Margunayasa, I Gede. 2015. "Analisis sikap sosial siswa kelas V pada pembelajaran dengan kurikulum 2013". E-journal PGSD universitas Pendidikan Ganesha, Volume 3, Nomor 1. http://dx.doi.org/10.23887/jjpgsd.v3i1.5631

Setiadi, Hari. 2016. "Pelaksanaan Penilaian Pada Kurikulum". Jurnal Penelitian dan Evaluasi Pendidikan, Volume 20, Nomor 2, Halaman (166-178). https://doi.org/10.21831/pep.v20i2.7173

Simamarta, Nada Naviana., Naniek Sulistya Wardani, Tego Prasetyo. 2019. "Pengembangan Instrumen Penilaian Sikap Toleransi Dalam Pebelajran Tematik Siswa Kelas IV SD". Jurnal Basicedu, Volume 3, Nomor 1, Halaman (194-199). https://doi.org/10.31004/basicedu.v3i1.101

Surahman, Edy., \& Mukminan. 2017. "Peran guru IPS sebagai pendidik dan pengajar dalam meningkatkan sikap sosial dan tanggung jawab sosial siswa SMP”. Harmoni Sosial: Jurnal Pendidikan IPS, Volume 4, Nomor 1, Halaman (1-13). https://doi.org/10.21831/hsjpi.v4i1.8660

Suryani, Elis., \& Aman, Aman. 2019. "Efektivitas pembelajaran IPS melalui implementasi metode jigsaw ditinjau dari aktivitas dan hasil belajar". Harmoni Sosial: Jurnal Pendidikan IPS, Volume 6, Nomor 1, Halaman (34-38). https://doi.org/10.21831/hsjpi.v6i1.17376

Tegeh, I Made., Simamora, Alexander Hamonangan, Dwipayana, Kadek. 2019. "Pengembangan Media video pembelajaran dengan model pengembangan 4D pada mata pelajaran Agama Hindu". Jurnal Mimbar Ilmu, Voume 24, Nomor 2, halaman (158-166). http://dx.doi.org/10.23887/mi.v24i2.21262

Utami, Atika Tri., \& Wardani, Naniek Sulistya Wardani. 2017. “Pengembangan instrumen penilaian kognitif pembelajaran IPS siswa kelas 4 SD gugus Kanigoro Tingkir Salatiga semester 2 tahun pelajaran 2016/2017". 2. https://repository.uksw.edu/handle/123456789/15619

Virani, Ida Ayu Dewi., Riastini, I Putu Nanci., \& Suarjana, I Made. 2016. "Deskripsi sikap sosial pada siswa kelas IV SD Negeri Penarukan kecamatan Buleleng Kabupaten Buleleng". E-Journal PGSD Universitas Pendidikan Ganesha, Volume 4, Nomor 1, Halaman (1-11). http://dx.doi.org/10.23887/jjpgsd.v4i2.7699

Wicaksono, Tulus Pamuji. Muhardjito. Titik Harsiati. 2016. "Pengembangan Penilaian Sikap Dengan Teknik Observasi, Self Assesment, dan Peer Assesment Pada Pembelajaran Tematik Kelas V SDN 
Arjowinangun 02 Malang". Jurnal Pendidikan, volume 1 Nomor 1 Halaman (45-51). http://dx.doi.org/10.17977/jp.v1i2.5214

Widiansyah, Apriyanti. 2017. "Peran ekonomi dalam pendidikan dan pendidikan dalam pembangunan ekonomi". Jurnal Cakrawala, Volume XVII, Nomor 2, Halaman (207-215). https://doi.org/10.31294/jc.v17i2.2612 